\title{
Ranking of Administrative Districts of Almaty City by Incidence of Hepatitis B and C
}

\author{
Lyazat Zh. Orakbay, $\mathrm{PhD}, \mathrm{ScD}$; ; Maria N. Omarova, $\mathrm{PhD}, \mathrm{ScD}$; \\ Idelbay Kh. Shuratov, PhD, ScD; Aizhan B. Dzhumagalieva, PhD \\ Scientific Centre of Hygiene and Epidemiology named after Hamza Zhumatov \\ Almaty, Kazakhstan
}

\begin{abstract}
The incidence of acute and chronic hepatitis $B$ and $C$ in the districts of Almaty city over the past 10 years is presented in this article. (International Journal of Biomedicine. 2017;7(3):240-242.)
\end{abstract}

Key words: acute hepatitis $\mathrm{B} \bullet$ acute hepatitis $\mathrm{C} \bullet$ chronic hepatitis $\mathrm{B} \bullet$ chronic hepatitis $\mathrm{C} \bullet$ vaccination

\section{Abbreviations}

AHB, acute hepatitis B; AHC, acute hepatitis C; CVH, chronic viral hepatitis; CHB, chronic hepatitis B; CHC, chronic hepatitis C; HBV, hepatitis B virus; HCV, hepatitis C virus.; MYI, multi-year indicator.

\section{Introduction}

Hepatitis B and C viruses are widely distributed among the population around the world. The World Health Organization (WHO) estimates more than 2 billion people have been infected with HBV, 360 million people are chronically infected, and 600000 people die annually from complications of HBV-related liver disease. ${ }^{(1,2)}$ Globally, an estimated 71 million people have chronic hepatitis $\mathrm{C}$ infection. $\mathrm{HCV}$ is approximately 10 times more infectious than HIV through percutaneous blood exposures and has been shown to survive for weeks in syringes. ${ }^{(3-5)} \mathrm{A}$ significant number of those who are chronically infected will develop cirrhosis or liver cancer. Approximately 399000 people die each year from hepatitis $\mathrm{C}$, mostly from cirrhosis and hepatocellular carcinoma. ${ }^{(6)}$ The number of deaths due to hepatitis $\mathrm{C}$ is at an all-time high in the US and exceeds those attributable to 60 other infectious diseases including HIV and tuberculosis, according to the Centers for Disease Control and Prevention. ${ }^{(7)}$ We analyzed

"Corresponding author: Lyazat Orakbay, PhD, ScD. Scientific Centre of Hygiene and Epidemiology named after Hamza Zhumatov. Almaty, Kazakhstan.E-mail: ncgigieny@mail.ru the incidence of acute and chronic hepatitis B and C in the districts of Almaty city over the past 10 years.

\section{Materials and Methods}

For the retrospective epidemiological analysis, we used the data of the official registration of the Department of Sanitary and Epidemiological Surveillance of Almaty for $\mathrm{HBV}$ and $\mathrm{HCV}$ in the intensive indicators (hepatitis incidence per 100,000 population) from 2003 to 2014 and the percent (\%) indicators by stratifications (age and socio-occupational groups) used with dichotomous variables.

The incidence of individual nosological forms of hepatitis in their total sum was expressed in the extensive (relative) indices. The behavior of the epidemic process was assessed by the annual dynamics of the cumulative incidence of hepatitis B and $C^{(8-10)}$

\section{Results and Discussion}

Table 1 shows the average incidence rate for AHB in Almaty's adult population at 4-year intervals for 20032014: the AHB incidence by city areas steadily decreased 
by 3 or more times. These data conclusively demonstrate the epidemiological effectiveness of HBV vaccination.

According to the indicators of the average multi-year incidence of AHB, the studied districts ranged in the following order (by rank): the Bostandyksky $\left(5.4 \%{ }_{0000}\right)$, Auezovsky $\left(4.8 \%{ }_{0000}\right)$, Zhetysusky $\left(4.3 \%{ }_{0000}\right)$, Almalinsky $\left(4.5 \%{ }_{0000}\right)$, Turksibsky $\left(4.1 \%{ }_{0000}\right)$, Medeusky $\left(2.8 \%{ }_{0000}\right)$, and Alatausky $\left(2.1 \%{ }_{0000}\right)$ districts.

\section{Table 1.}

The average incidence rate for $A \mathrm{HB}$ by the districts of Almaty for 2003-2014

\begin{tabular}{|c|c|c|c|c|c|}
\hline \multirow[b]{2}{*}{ Districts } & \multicolumn{3}{|c|}{ MYI at 4-year intervals $\left(\%{ }_{0000}\right)$} & \multirow{2}{*}{$\begin{array}{l}\text { Rate of } \\
\text { decrease }\end{array}$} & \multirow{2}{*}{$\begin{array}{l}\text { MYI } \\
(\% / 0000\end{array}$} \\
\hline & 2003-2006 & $2007-2010$ & 2011-2014 & & \\
\hline Almalinsky & 9.3 & 3.1 & 1.1 & 8.4 & 4.5 \\
\hline Turksibsky & 6.6 & 3.6 & 2.2 & 3.0 & 4.1 \\
\hline Zhetysusky & 8.9 & 2.9 & 4.15 & 7.7 & 4.3 \\
\hline Bostandyksky & 9.3 & 3.5 & 3.6 & 2.6 & 5.4 \\
\hline Medeusky & 4.4 & 3.1 & 0.92 & 4.7 & 2.8 \\
\hline Auezovsky & 6.2 & 6.5 & 1.9 & 3.2 & 4.8 \\
\hline Alatausky & - & 4.5 & 1.6 & 2.8 & 2.1 \\
\hline
\end{tabular}

The results of a similar analysis for AHC incidence are shown in Table 2. Thus, during 2003-2014, AHC indicators for districts ranged from $0.25 \%$ o000 $2.7 \%$ o000. According to the average multi-year incidence, the Auezovsky district $(1.3 \%$ took the first place. During subsequent years, these indicators were equal to zero in some districts or were very low due to registration of single cases of AHC. Apparently, comparatively more pronounced indicators in 2003-2006 are associated with deficiencies of the specific qualities (sensitivity, specificity, etc.) of the first batches of diagnostic test systems for ELISA.

Table 2.

The average incidence rate for $A H C$ by the districts of Almaty for 2003-2014

\begin{tabular}{|l|c|c|c|c|c|}
\hline \multirow{2}{*}{ Districts } & \multicolumn{2}{|c|}{ MYI at 4-year intervals $\left(\%{ }_{0000}\right)$} & Trend & $\begin{array}{c}\text { MYI } \\
\left(\% \%_{0000}\right)\end{array}$ \\
\cline { 2 - 4 } & $2003-2006$ & $2007-2010$ & $2011-2014$ & & $1.38 \downarrow$ \\
\hline Almalinsky & 1.8 & 0.0 & 1.3 & 1.03 \\
\hline Turksibsky & 0.25 & 0.06 & 0.0 & - & 0.08 \\
\hline Zhetysusky & 0.35 & 0.17 & 0.0 & - & 0.17 \\
\hline Bostandyksky & 0.8 & 0.4 & 0.0 & - & 0.4 \\
\hline Medeusky & 0.45 & 0.85 & 0.2 & $2.25 \downarrow$ & 0.5 \\
\hline Auezovsky & 2.7 & 0.9 & 0.3 & $9.0 \downarrow$ & 1.3 \\
\hline Alatausky & - & 0.5 & 1.6 & $0.3 \uparrow$ & 0.7 \\
\hline
\end{tabular}

However, it should be noted that unlike with AHBin which the IgM antibody to the hepatitis B core antigen is diagnostic of acute infection and precedes the appearance of IgG-with $\mathrm{HCV}$ infection the IgM antibody responses are variably detected in both acute and chronic phases. ${ }^{(11)}$ Anti$\mathrm{HCV}$ IgM cannot therefore serve as a diagnostic marker of acute $\mathrm{HCV}$ infection. ${ }^{(12)}$
Thus, the assessment of dynamics of incidence of AHB and $\mathrm{AHC}$ showed that the incidence rate for AHB dropped sharply, and isolated cases of AHC were in fact cases of CHC. Based on these considerations, our studies in the regions were focused mainly on the problems of chronic hepatitis $\mathrm{C}$, as the most relevant infection for public health.

The analysis of the incidence of $\mathrm{CHB}$ and $\mathrm{CHC}$ by the districts of Almaty for 2003-2014 is presented in Tables 3 and 4. During the analyzed period, in the study areas, with the exception of the Medeusky and Auezovsky districts, there was a decrease in the incidence of CHB in the range from 1.2 to 3.6 times. In the Medeusky and Auezovsky districts, we observed that the incidence rate of CHB increased by 1.2 and 1.5 times, respectively.

Table 3.

The average incidence rate for $\mathrm{CHB}$ by the districts of Almaty for 2003-2014

\begin{tabular}{|l|c|c|c|c|c|}
\hline \multirow{2}{*}{ Districts } & \multicolumn{2}{|c|}{ MYI at 4-year intervals $\left(\%{ }_{0000}\right)$} & Trend & $\begin{array}{c}\text { MYI } \\
\left(\% \%_{0000}\right)\end{array}$ \\
\cline { 2 - 6 } & $2003-2006$ & $2007-2010$ & $2011-2014$ & & 4.8 \\
\hline Almalinsky & 6.4 & 4.2 & 3.9 & $1.6 \downarrow$ & 4.8 \\
\hline Turksibsky & 2.2 & 2.8 & 0.6 & $3.6 \downarrow$ & 1.9 \\
\hline Zhetysusky & 0.15 & 2.1 & - & - & 1.4 \\
\hline Bostandyksky & 6.2 & 6.1 & 5.7 & $1.2 \downarrow$ & 6.0 \\
\hline Medeusky & 6.2 & 6.4 & 7.2 & $1.2 \uparrow$ & 6.6 \\
\hline Auezovsky & 5.8 & 8.7 & 12.5 & $2.0 \uparrow$ & 9.0 \\
\hline Alatausky & - & 3.7 & 1.9 & $1.9 \downarrow$ & 1.8 \\
\hline
\end{tabular}

Table 4.

The average incidence rate for $\mathrm{CHC}$ by the districts of Almaty for 2003-2014

\begin{tabular}{|l|c|c|c|c|c|}
\hline \multirow{2}{*}{ Districts } & \multicolumn{2}{|c|}{$\begin{array}{c}\text { Multi-year indicators at 4-year } \\
\text { intervals }\left(\%{ }_{0000}\right)\end{array}$} & Trend & $\begin{array}{c}\text { MYI } \\
(\%)\end{array}$ \\
\cline { 2 - 4 } & $2003-2006$ & $2007-2010$ & $2011-2014$ & & \\
\hline Almalinsky & 3.9 & 3.1 & 4.1 & $1.05 \uparrow$ & 3.7 \\
\hline Turksibsky & 2.5 & 1.4 & 2.9 & $1.3 \uparrow$ & 2.3 \\
\hline Zhetysusky & 2.1 & 0.2 & - & - & 1.4 \\
\hline Bostandyksky & 8.9 & 9.5 & 9.9 & $1.1 \uparrow$ & 9.4 \\
\hline Medeusky & 3.5 & 1.3 & 11.5 & $3.3 \uparrow$ & 5.4 \\
\hline Auezovsky & 7.9 & 13.1 & 21.3 & $2.6 \uparrow$ & 11.6 \\
\hline Alatausky & - & 1.3 & 1.9 & $1.4 \uparrow$ & 1.05 \\
\hline
\end{tabular}

Thus, CHC was registered in all districts of the city. Moreover, during the observed period, there was a tendency for the $\mathrm{CHC}$ incidence to grow from 1.1 to 3.3 times. The most noticeable growth was observed in the Medeusky (3.3 times) and Auezovsky (2.6 times) districts.

The analyses of the multi-year incidences of $\mathrm{CHB}$ and $\mathrm{CHC}$, with rank positions for districts, are presented in Tables 5 and 6 . In the ranking of districts with a decrease in the multi-year incidence of CHB and CHC (per 100 thousand population), the first three ranks were occupied by the same 
districts in which the incidence rate for $\mathrm{CHB}$ and $\mathrm{CHB}$ was the highest. These results may indicate the identity of the mode of transmission for $\mathrm{HBV}$ and $\mathrm{HCV}$ in these regions.

\section{Table 5.}

The 2003-2014 multi-year incidences of $\mathrm{CHC}$ with rank positions for districts

\begin{tabular}{|l|c|c|}
\hline \multicolumn{1}{|c|}{ Districts } & MYI $\left(\%{ }_{0000}\right)$ & Rank number \\
\hline Auezovsky & 11.6 & 1 \\
\hline Bostandyksky & 9.4 & 2 \\
\hline Medeusky & 5.4 & 3 \\
\hline Almalinsky & 3.7 & 4 \\
\hline Turksibsky & 2.3 & 5 \\
\hline Zhetysusky & 1.4 & 6 \\
\hline Alatausky & 1.05 & 7 \\
\hline
\end{tabular}

\section{Table 6.}

The 2003-2014 multi-year incidences of CHB with rank positions for districts

\begin{tabular}{|l|c|c|}
\hline \multicolumn{1}{|c|}{ Districts } & MYI $\left(\%{ }_{0000}\right)$ & Rank number \\
\hline Auezovsky & 9.6 & 1 \\
\hline Medeusky & 6.6 & 2 \\
\hline Bostandyksky & 6.0 & 3 \\
\hline Almalinsky & 4.8 & 4 \\
\hline Turksibsky & 1.9 & 5 \\
\hline Alatausky & 1.8 & 6 \\
\hline Zhetysusky & 1.4 & 7 \\
\hline
\end{tabular}

\section{Conclusion}

Thus, as a whole, we observed a tendency toward a gradual decrease in the incidence of CHB in the districts of Almaty city. Assessment of the hepatitis $\mathrm{C}$ incidence by the cumulative indices reflects the disturbing epidemiological situation for this disease that requires the effective and quality monitoring of hepatitis $\mathrm{C}$.

\section{Competing interests}

The authors declare that they have no competing interests.

\section{References}

1. WHO. Hepatitis B. Available from: http://www.who.int/ mediacentre/factsheets/fs204/en/ Accessed June 22, 2014.

2. Hepatitis B vaccines: WHO position paper, October 2009. WER. Available from: http://www.who.int/wer/2009/ wer8440/en/

3. Sulkowski MS, Moore RD, Mehta SH, Chaisson RE, Thomas DL. Hepatitis C and progression of HIV disease. JAMA. 2002;288(2):199-206.

4. Ciesek S, Friesland M, Steinmann J, Becker B, Wedemeyer $\mathrm{H}$, Manns MP, et al. How stable is the hepatitis $\mathrm{C}$ virus (HCV)? Environmental stability of HCV and its susceptibility to chemical biocides. J Infect Dis. 2010;201(12):1859-66. doi: 10.1086/652803.

5. Paintsil E, He H, Peters C, Lindenbach BD, Heimer R. Survival of hepatitis $C$ virus in syringes: implication for transmission among injection drug users. J Infect Dis. 2010;202(7):984-90. doi: 10.1086/656212.

6. WHO. Hepatitis C Fact sheet. Updated July 2017. Available from: http://www.who.int/mediacentre/factsheets/ fs164/en/

7. Surveillance for Viral Hepatitis - United States, 2014. Available from: https://www.cdc.gov/hepatitis/ statistics/2014surveillance/index.htm

8. Utegenova ES, Shuratov IKh, Khan OE. [Hepatitis C morbidity in Kazakhstan]. Gigiena Epidemiologia I Immunologia. 2008;(3):66-70. [Article in Russian].

9. Mukomolov S, Trifonova G, Levakova I, Bolsun D, Krivanogova E. Hepatitis C in the Russian Federation: challenges and future directions. Hepat Med. 2016; 8: 51-60. Published online 2016 May 5. doi: 10.2147/HMER.S50172 10. Klushkina VV, Kyuregyan KK, Kozhanova TV, Popova OE, Dubrovina PG, Isaeva OV, et al. Impact of Universal Hepatitis B Vaccination on Prevalence, Infection-Associated Morbidity and Mortality, and Circulation of Immune Escape Variants in Russia. PLoS One. 2016; 11(6): e0157161.Published online 2016 Jun 9. doi: 10.1371/journal.pone.0157161

11. Quinti I, Hassan NF, El Salman D, Shalaby H, El Zimatty $\mathrm{D}$, Monier MK, Arthur RR. Hepatitis C virus-specific B cell activation: IgG and IgM detection in acute and chronic hepatitis C. J Hepatol. 1995;23:640-7.

12. Pawlotsky JM. Molecular diagnosis of viral hepatitis. Gastroenterology. 2002;122(6):1554-68. 